\title{
Diagnostic Problems in Severe Neonatal Jaundice and G6PD Deficiency in Greece ${ }^{\star}$
}

\author{
L. ZANNOS-MARIOLEA, TH. THOMAIDIS, G. GEORGIZASt, \\ E. GAVRIELIDOU, and S. BENETOS \\ From the Blood Division of the Choremion Research Laboratory, Department of Pediatrics, University of Athens
}

Since the first observation in Greece by Doxiadis, Fessas, and Valaes in 1960, it is now well established that a considerable proportion of full-term Greek newborns with severe jaundice (and/or anaemia) have G6PD deficiency. Similar cases have been described in other parts of the world (Freier, Mayer, Levene, and Abrahamov, 1965).

G6PD deficiency and increased haemolysis are obviously cause and effect when newborns have been exposed to drugs and chemicals known to cause haemolysis in G6PD deficiency in general. However, about $50 \%$ of deficient newborns who develop severe jaundice with or without obvious haemolysis have not been exposed to one of these drugs. This particular group of babies has aroused considerable interest, research, and speculation; nevertheless, the pathogenesis of the jaundice remains obscure.

In the present study we intend to expose the difficulties involved in the diagnosis of G6PD deficiency in the newborn, and especially in newborns who develop severe jaundice. The diagnostic aspects of this problem have both a practical and a theoretical interest. They are not irrelevant to the pathogenesis of jaundice. Any speculation on the mechanism of severe jaundice in babies with G6PD deficiency, and particularly in those who have not been exposed to the action of a known haemolytic compound, should take into consideration the causes underlying the diagnostic difficulties.

\section{Material and Methods}

Studies were made of 302 full-term newborns (185 male; 117 female) younger than 15 days who were referred to the Paediatric Clinic of Athens University during a three-year period (1964-1967) because of severe jaundice and/or anaemia.

\footnotetext{
Received April 12, 1967.

* This work was supported in part by a grant (743) of the Royal Hellenic Research Foundation.

† Fellow of Royal Hellenic Research Foundation.
}

The level of indirect bilirubin was above $20 \mathrm{mg} . / 100$ $\mathrm{ml}$. in 241 cases $(79 \cdot 7 \%)$. In 55 newborns it ranged from 15 to $19.9 \mathrm{mg} . / 100 \mathrm{ml}$. In neonates with $\mathrm{Rh}$ isoimmunization, in whom the diagnosis was made early, and in 2 others with G6PD deficiency and naphthalene-induced acute haemolysis, indirect bilirubin levels were below $15 \mathrm{mg} . / 100 \mathrm{ml}$., but in these cases there was also severe anaemia (Hb less than $8 \mathrm{~g} . / 100 \mathrm{ml}$.).

In the 302 above-mentioned newborns the following diagnostic procedures were carried out.

Serum bilirubin was determined by the method of Malloy and Evelyn (1937); haemoglobin, reticulocyte count, Heinz bodies, $\mathrm{Rh}$ factor, and blood group determination by the standard techniques; dry blood smears, in almost all cases. Direct Coombs test in all cases; and liver function tests and haemoglobin electrophoresis on

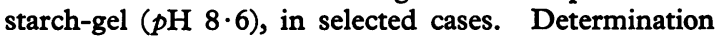
of G6PD of red cell activity was assessed by three different methods: quantitative, methaemoglobin-elution test, and glutathione stability test.

(1) Quantitative measurement of G6PD activity. The reagents supplied in the G6PD kit (Biochemica, Boehringer) were used and G6PD activity was measured by following the rate of reduction of triphosphopyridine nucleotide (TPN) at $340 \mathrm{~m} \mu$. The enzyme unit was defined as the activity of G6PD which produced an optical density change of 1.00 per minute per $3 \mathrm{ml}$. reaction mixture at $25^{\circ} \mathrm{C}$. In our laboratory the mean value of G6PD activity in normal full-term neonates is 434 units, with a standard deviation of \pm 56 . Values below 322 units, i.e. two standard deviations below the mean, are considered pathological.

(2) 'Methaemoglobin-elution' test (as applied by Sansone, Rasore-Quartino, and Veneziano, 1963). This test is a combination of Brewer's methaemoglobin reduction test and Kleihauer and Betke's cyanmethaemoglobin elution technique. It permits the diagnosis of G6PD deficiency in the individual red cell, since deficient erythrocytes do not reduce methaemoglobin efficiently, and upon elution of methaemoglobin they appear empty. The percentage of methaemoglobin present at the end of the incubation period (Brewer's test) was not measured spectrophotometrically. The results of Brewer's test were noted by visual examination of a 

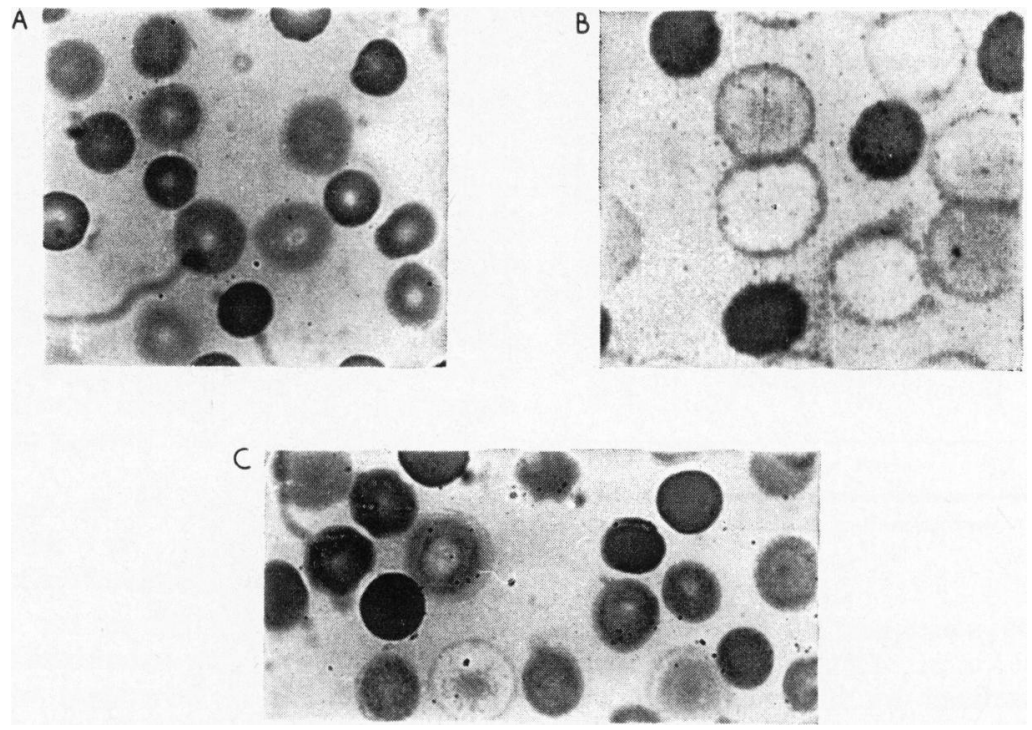

Fig. 1.-Methaemoglobin-elution test: $(A)$ and $(C)$ males with mild G6PD deficiency (Cases 3 and 9, Table III). Red cells show all grades of decoloration. (B) Female heterozygote for G6PD deficiency. Only two populations of red cells are present: normal and G6PD deficient (empty) cells.

$1: 100$ haemolysate of the incubated blood. If a brown discoloration of the haemolysate was observed the test was expressed as $3+$ positive and was indicative of severe G6PD deficiency. Normal haemolysates had a bright red colour. In heterozygous females the colour varied from red to light brown, i.e. $1+$ to $2+$.

After the process of elution, all blood smears were examined by only one of the authors (L.Z.M.). The finding of empty cells, even in the order of $0.5 \%$, in females, if constant, after repetition of the test, was considered indicative of G6PD deficiency. In the experience of the author, no empty cells are seen in normal subjects. The evaluation of the test was more difficult in hemizygous males with the mild deficiency type, where all grades of decoloration were observed. Needless to say, experience is needed to distinguish this type of deficiency from a technically unsatisfactory normal smear (Fig. 1).

(3) Glutathione stability test (as modified by Beutler, Duron, and Kelly, 1963). This method is considered an accurate one. The standard deviation in our laboratory is $\pm 0.9 \mathrm{mg} . / 100 \mathrm{ml}$. packed red cells. Post-incubation values of reduced glutathione (GSH) below $40 \mathrm{mg} . / 100 \mathrm{ml}$. packed red cells are considered pathological (Beutler et al., 1963).

Parents, whenever available, were also examined by these three methods. It should be noted that large numbers of our babies were referred from provincial towns, so that their post-partum mothers did not accompany them as a rule. However, information about their blood group was obtained in most cases. Findings in parents will only be reported, where neces- sary, to confirm a doubtful diagnosis of G6PD deficiency in the newborn.

\section{Results}

The results of the application of the 3 diagnostic methods for G6PD deficiency in the 302 newborns are represented in Table $I$, and are as follows.

A. Quantitative measurement for G6PD activity: the enzyme activity was measured in all 302 newborns, it was pathological (below 322 units), in 51 males and 21 females.

B. 'Combined' methaemoglobin-elution test: this test was applied to 266 newborns. It was found

\section{TABLE I}

Results of Application of 3 Different Diagnostic Methods for G6PD Deficiency in 302 Full-term Newborns with Severe Jaundice and/or Anaemia

\begin{tabular}{|c|c|c|c|}
\hline $\begin{array}{l}\text { No. of } \\
\text { Newborns } \\
\text { Examined }\end{array}$ & $\begin{array}{c}\text { G6PD } \\
\text { Activity } \\
\text { Below } 322 \text { U }\end{array}$ & $\begin{array}{c}\text { Methaemoglo- } \\
\text { bin-elution } \\
\text { Test: No. } \\
\text { Deficient }\end{array}$ & $\begin{array}{c}\text { Glutathione } \\
\text { Stability } \\
\text { Test: No. } \\
\text { Deficient }\end{array}$ \\
\hline 302 & \multirow{3}{*}{$\begin{array}{ll}M & 51 \\
\text { F } & 21\end{array}$} & \multirow{3}{*}{$\begin{array}{ll}M & 59 \\
F & 40\end{array}$} & \\
\hline 266 & & & \\
\hline 223 & & & $\begin{array}{lr}M & 37 \\
\text { F } & 197\end{array}$ \\
\hline $\begin{array}{c}\text { Total number } \\
\text { G6PD } \\
\text { deficient }\end{array}$ & 72 & 99 & 56 \\
\hline
\end{tabular}


TABLE II

Non-G6PD Deficient Newborns with Severe Jaundice and/or Anaemia, Grouped According to Aetiology

\begin{tabular}{|c|c|c|c|c|}
\hline Groups & $\begin{array}{c}\text { No. of } \\
\text { Newborns }\end{array}$ & Males & Females & $\mathbf{M}: \mathbf{F}$ ratio \\
\hline $\begin{array}{l}\text { I: ABO isoim- } \\
\text { munization } \\
\text { II: } A B O \text { set-up } . \\
\text { III: Rh isoim- } \\
\text { munization } \\
\text { IV: Naphthalene } \\
\text { exposure } \\
\text { V: Unknown } \\
\text { VI: Miscellaneous }\end{array}$ & $\begin{array}{l}54 \\
29 \\
\\
21 \\
\\
14 \\
70 \\
15\end{array}$ & $\begin{array}{l}31 \\
17 \\
\\
13 \\
\\
12 \\
42 \\
11\end{array}$ & $\begin{array}{r}23 \\
12 \\
8 \\
2 \\
28 \\
4\end{array}$ & $\begin{array}{l}1 \cdot 34 \\
1 \cdot 41 \\
1 \cdot 62 \\
6 \\
1 \cdot 5 \\
2 \cdot 75\end{array}$ \\
\hline Total & 203 & 126 & 77 & $1 \cdot 63$ \\
\hline
\end{tabular}

$\star$ Miscellaneous $=$ newborns with cyanosis, septicaemia, mongolism, etc.

pathological in 59 males and 40 females, i.e. in $33 \%$ of the total cases. Of the 36 cases which could not be examined by this method, 5 were cases of $\mathrm{Rh}$ isoimmunization, 8 of $\mathrm{ABO}$ isoimmunization (spherocytosis present), 9 of doubtful ABO isoimmunization (ABO set up, without spherocytosis), and 14 of 'unknown aetiology'.

C. Glutathione (GSH) stability test: this test was applied to 223 newborns and found to be pathological in 37 males and 19 females.

These results indicate that the greatest number of G6PD deficient newborns were detected by the methaemoglobin-elution test, i.e. 99 newborns as compared to 72 by the quantitative method and 56 by the GSH stability test. Of the 99 deficient babies, 59 were male and 40 were female. Hence the male : female ratio was $1 \cdot 47$.

Of the 99 G6PD deficient babies, 34 have been exposed to one of the known toxic drugs, mostly naphthalene. 9 were cases of $\mathrm{ABO}$ incompatibility as well, one of $R h$ isoimmunization, and 55 had not been exposed to any of the drugs known to cause haemolysis in 'sensitive' subjects. However, the mothers of these babies were usually given pethidine, hyoscine butylbromide, and vasopressin during labour, and in the great majority tetracycline was given during the first few days post partum, while their babies were breast feeding.

The remaining 203 newborns who did not have G6PD deficiency were divided into 6 groups (I-VI) according to certain aetiological criteria, as shown in Table II. In 70 cases, or $23 \%$ of the total of newborns, the aetiology of severe jaundice remained unknown. This percentage is in reality higher if it is considered that a number of babies of group 2 were probably not cases of $\mathrm{ABO}$ isoimmunization.

The male : female ratio of these 203 babies is 1.63 (males 126; females 77; Table II), i.e. not significantly different from that observed in the G6PD deficient group. Interestingly enough, males predominated in all groups. Group IV deserves comment; it included babies who developed severe jaundice after exposure to naphthalene, despite their normal G6PD activity. Such cases have been described already in Greece (Valaes, Doxiadis, and Fessas, 1963). The impressive predominance of males is reminiscent of childhood favism, where the male : female ratio is about 10 (Zannos-Mariolea and Kattamis, 1961). It is unfortunate that the number of cases in this group is too small to draw any conclusions.

\section{Analysis of Results in 99 Newborn G6PD Deficient Newborns by Methaemoglobin Elution Method}

Females. Fig. 2 shows the distribution of G6PD activity values as determined by the quantitative method. It is interesting to note that 19 $(47 \cdot 5 \%)$ of the 40 G6PD females deficient by the elution method had normal values of enzyme activity. On the other hand, the GSH stability was assayed in 37 of the 40 females and was pathological in 18 , i.e. $48.6 \%$ of the cases. Of these, 6 had normal values of G6PD activity. On the other hand, 7 females with low G6PD activity had normal GSH stability.

The above data strongly suggest that a great proportion of female jaundiced babies are heterozygous, since homozygous females have very low values of enzyme activity comparable to those found

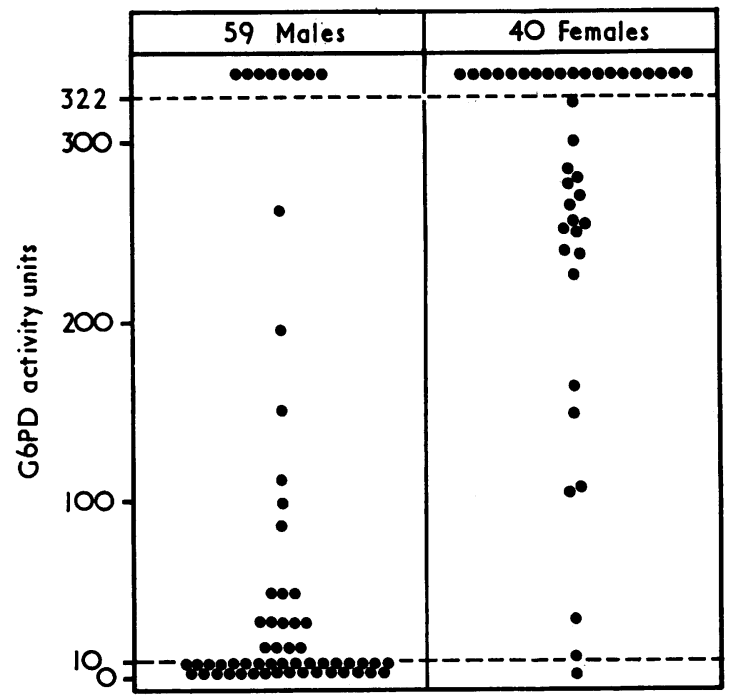

Fig. 2.-G6PD values of 59 males and 40 females estimated by the quantitative method. 
TABLE III

Data on 11 Male Newborns with the Mild Type of Deficiency

\begin{tabular}{|c|c|c|c|c|c|c|c|c|c|c|c|}
\hline \multirow[t]{2}{*}{$\begin{array}{l}\text { Case } \\
\text { No. }\end{array}$} & \multirow[t]{2}{*}{$\begin{array}{l}\text { Age } \\
\text { (dy.) }\end{array}$} & \multirow[t]{2}{*}{$\begin{array}{c}\mathrm{Hb} \\
(\mathrm{g} . / \\
100 \mathrm{ml} .)\end{array}$} & \multirow[t]{2}{*}{$\begin{array}{c}\text { Indirect } \\
\text { Bili- } \\
\text { rubin } \\
(\mathrm{mg} . / \\
100 \mathrm{ml} .)\end{array}$} & \multirow[t]{2}{*}{$\begin{array}{l}\text { G6PD } \\
\text { Acti- } \\
\text { vity } \\
\text { (units) }\end{array}$} & \multicolumn{2}{|c|}{$\begin{array}{c}\text { GSH } \\
\text { Stability } \\
\text { (mg./100 ml. } \\
\text { packed red } \\
\text { cells) }\end{array}$} & \multirow[t]{2}{*}{$\begin{array}{c}\text { Brewer's } \\
\text { Methae- } \\
\text { moglobin } \\
\text { Reduction } \\
\text { Test }\end{array}$} & \multirow[t]{2}{*}{$\begin{array}{l}\text { Methaemo- } \\
\text { globin-elution } \\
\text { Test }\end{array}$} & \multirow[t]{2}{*}{ Drug } & \multirow[t]{2}{*}{ Mother } & \multirow[t]{2}{*}{ Remarks } \\
\hline & & & & & Pre & Post & & & & & \\
\hline 1 & 9 & $10 \cdot 9$ & 46 & 150 & - & - & +++ & Pathological & - & Deficient & $\begin{array}{l}\text { Kernikterus; } \\
\text { died }\end{array}$ \\
\hline $\begin{array}{r}2 \\
3 \\
4 \\
5 \\
6 \\
7 \\
8 \\
9 \\
10 \\
11\end{array}$ & $\begin{array}{r}6 \\
11 \\
5 \\
5 \\
7 \\
6 \\
5 \\
5 \\
6 \\
4\end{array}$ & $\begin{array}{r}14 \cdot 3 \\
8 \cdot 3 \\
5 \cdot 3 \\
18 \cdot 4 \\
13 \cdot 3 \\
20 \\
14 \cdot 8 \\
14 \cdot 5 \\
18 \cdot 4 \\
16 \cdot 5\end{array}$ & $\begin{array}{l}31 \cdot 8 \\
40 \\
27 \\
19 \cdot 3 \\
24 \\
34 \\
31 \cdot 6 \\
28 \cdot 6 \\
22 \cdot 4 \\
20\end{array}$ & $\begin{array}{l}193 \\
267 \\
385 \\
393 \\
616 \\
345 \\
388 \\
431 \\
576 \\
454\end{array}$ & $\begin{array}{l}54 \\
86 \\
32 \\
85 \\
81 \\
80 \\
90 \\
66 \\
56\end{array}$ & $\begin{array}{l}32 \\
65 \\
28 \\
49 \\
81 \\
11 \\
67 \\
27 \\
38\end{array}$ & $\begin{array}{l}- \\
++ \\
+++ \\
+++ \\
+++ \\
+++ \\
+++ \\
+++ \\
+++\end{array}$ & $\begin{array}{l}\text { Pathological } \\
\text { Pathological } \\
\text { Pathological } \\
\text { Pathological } \\
\text { Pathological } \\
\text { Pathological } \\
\text { Pathological } \\
\text { Pathological } \\
\text { Pathological } \\
\text { Pathological }\end{array}$ & $\begin{array}{l}\text { Naphthalene } \\
\text { Vitamin K } \\
\text { Naphthalane } \\
\text { = } \\
\text { = }\end{array}$ & $\begin{array}{l}\text { Deficient } \\
\text { Deficient } \\
\text { Deficient } \\
\text { Deficient } \\
\text { Deficient } \\
\text { Deficient } \\
\text { Not examined } \\
\text { Not examined } \\
\text { Normal } \\
\text { Not examined }\end{array}$ & Kernikterus \\
\hline
\end{tabular}

in hemizygous males. This view has already been expressed by other Greek authors (Fessas, Doxiadis, and Valaes, 1962). Using Motulsky's semiquantitative test they detected jaundiced female newborns with normal enzyme activity whose fathers were G6PD deficient. However, in order to prove heterozygosity, one should find a deficient baby of a normal father, since a normal appearing mother could still be a carrier of the deficiency. These prerequisites are fulfilled in 11 of the 40 females of this study. In 8 other girls, the father was found to be G6PD deficient. The fathers of 21 girls were not available for examination. It is probable, however, that many more females are heterozygotes, since, in 25 of the cases which did not fulfil the criteria of heterozygosity, the enzyme activity was above 225 units; only 3 cases had values of activity below 50 units, as observed in homozygotes.

The great superiority of the 'methaemoglobinelution test' over the quantitative determination of G6PD activity, when both were applied to newborn females, should be attributed to the fact that normal newborn red cells have high G6PD activity compared to normal adults (Gross and Hurwitz, 1958). Thus in heterozygous G6PD deficient newborns, the high activity of the normal red cell population could compensate for the low or zero activity of deficient red cells to such an extent that the end result of the quantitative method would be that of a normal enzyme activity.

Males. Fig. 2 illustrates the distribution of G6PD activity values of the 59 G6PD deficient males. Zero values ( $<10$ units) were found in 33 , i.e. in $56 \%$ of the male newborns, whereas in 8 newborns, found to be deficient in G6PD by the methaemoglobin-elution method, total enzyme activity was quantitatively normal ( $>322 \mathrm{U}$ ). In the remaining 18 cases enzyme values scattered from 10 to $267 \mathrm{U}$.

The GSH stability test was performed in 40 of these cases, and was pathological in 37 . It is interesting to note that the 3 males with normal GSH stability also had normal values of G6PD activity.

Data, such as means of age, haemoglobin, and indirect bilirubin, as well as results of the 3 diagnostic methods employed for the detection of G6PD deficiency, on the 8 deficient males (Cases 4-11) with normal measurements of G6PD activity, are illustrated in Table III. In this Table we have also included, for comparison, the findings of 3 males (Cases 1-3) with the mild type of G6PD deficiency. The findings in detail of mothers of these newborns are presented in Table IV.

The diagnosis of G6PD deficiency in the 8 males with normal G6PD activity was based on the results obtained with the methaemoglobin-elution method. These are comparable to those obtained in the 3 hemizygous males with the mild type of G6PD deficiency (Cases 1, 2, and 3). Nevertheless, the diagnosis is debatable, in view of the difficulties involved in interpreting results of the mild type of deficiency by the methaemoglobin-elution test.

This is why Cases 8,10 , and 11 would not have been considered, had they not been supported by similar findings from Cases $4,5,6,7$, and 9 in which GSH stability and/or Brewer's test were also abnormal, and which were newborns of proven deficient mothers (Table IV).

\section{Discussion}

This study shows the difficulties involved in the diagnosis of G6PD deficiency during the newborn 
TABLE IV

Data on Mothers of 8 Male Newborns with Mild Type of Deficiency, Examined by Three Diagnostic Methods

\begin{tabular}{|c|c|c|c|c|c|c|}
\hline \multirow{3}{*}{$\begin{array}{l}\text { Case No. of } \\
\text { Child }{ }^{\star}\end{array}$} & \multicolumn{6}{|c|}{ Data on Mothers } \\
\hline & \multirow{2}{*}{$\begin{array}{l}\text { G6PD Activity } \\
\text { (units) }\end{array}$} & \multicolumn{2}{|c|}{$\begin{array}{c}\text { GSH Stability } \\
\text { (mg./100 ml. packed red cells) }\end{array}$} & \multirow{2}{*}{$\begin{array}{l}\text { Brewer's } \\
\text { Methaemoglobin } \\
\text { Reduction Test }\end{array}$} & \multirow{2}{*}{$\begin{array}{l}\text { Methaemoglobin- } \\
\text { elution Test }\end{array}$} & \multirow[t]{2}{*}{ Diagnosis } \\
\hline & & Pre & Post & & & \\
\hline $\begin{array}{r}1 \\
2 \\
3 \\
4 \\
5 \\
6 \\
7 \\
10\end{array}$ & $\begin{array}{r}169 \\
220 \\
59 \\
224 \\
98 \\
310 \\
205 \\
404\end{array}$ & $\begin{array}{l}84 \\
41 \\
94 \\
70 \\
86 \\
78\end{array}$ & $\begin{array}{l}74 \\
14 \\
74 \\
59 \\
86 \\
76\end{array}$ & $\begin{array}{c}++ \\
+ \\
++ \\
- \\
++ \\
+ \\
+\end{array}$ & $\begin{array}{l}\text { Pathological } \\
\text { Pathological } \\
\text { Pathological } \\
\text { Pathological } \\
\text { Pathological } \\
\text { Pathological } \\
\text { Pathological } \\
\text { Normal }\end{array}$ & $\begin{array}{l}\text { Deficient } \\
\text { Deficient } \\
\text { Deficient } \\
\text { Deficient } \\
\text { Deficient } \\
\text { Deficient } \\
\text { Deficient } \\
\text { Normal }\end{array}$ \\
\hline
\end{tabular}

$\star$ See Table III.

period, particularly in females. It also indicates the necessity of using the methaemoglobin-elution test in addition to the other two methods.

The methaemoglobin-elution test has not been used previously in Greece for the investigation of newborns with severe jaundice. Hence, the different (higher) male : female ratio reported by other Greek authors (Doxiadis and Valaes, 1964), i.e. 3.0 as compared to 1.47 in this study, indicating that a certain number of deficient females had previously escaped the diagnosis. This probably occurred in the present study as well, since even in adult heterozygotes this test is not $100 \%$ efficient in the diagnosis of G6PD deficiency. Moreover, the parents of the female newborns were not always available for study.

Beutler and Baluda (1963) reported evidence of interaction between normal and deficient newborn red cells, during the performance of this test, where normal erythrocytes facilitate reduction of methaemoglobin in deficient red cells. This effect was attributed to leukomethylene blue, the reduced form of methylene blue. Beutler suggested the replacement of methylene blue by nile sulphate which produces no such interaction. Using this modified technique, Gall, Brewer, and Dern (1965) found more than $7 \%$ empty (deficient) cells in heterozygotes and less than $6 \%$ in normal individuals. This author believes that there may be overlap as a greater number of subjects are studied. For this reason, and also because the greatest part of this work had already been done when we came across Beutler's modified method, we stuck to the use of methylene blue.

It would be interesting to see whether jaundice and anaemia are less severe in heterozygotes than in hemizygotes with zero activity. Our data do not corroborate this, but the number of cases is too small for any conclusions to be drawn.

The group of male infants G6PD deficient by the methaemoglobin elution test, but with normal enzyme activity, is an interesting one; the interpretation of results obtained with the methaemoglobinelution test is not as easy as in the heterozygotes.

We are probably dealing with cases of mild G6PD deficiency, as described already in Greece by Stamatoyannopoulos, Panayotopoulos, and Papayannopoulou (1964). The normal enzyme values in this group apparently reflect the enzyme activity of a young red cell population (Carson and Frischer, 1966), the old red cells with low activity having been destroyed. Something similar occurs in favism. Values of enzyme activity between 10-50 units are observed occasionally during the haemolytic crisis in children who have zero activity during periods of rest. It is true, however, that haemolysis in our group of males is as a rule less acute than in favism, but on the other hand newborn red cells consist of a younger red cell population and have a higher enzyme activity as compared to older children.

So far we have not been able to re-examine these male infants. We can only guess that at an older age their enzyme activity will probably be at the low normal range or definitely abnormal. According to Stamatoyannopoulos et al. (1964), Greek adults with the mild range of G6PD deficiency have values of activity ranging between $5-75 \%$ of the normal mean. The above authors make the suggestion that heterogeneity of G6PD activity values may be due to heterogeneity of the G6PD deficiency gene, since the 'mild' type shows a tendency for a focal geographical distribution which does not correlate with the total frequency of G6PD deficiency. Moreover, quite recently, variants of the G6PD deficiency gene have been found to exist in certain areas of Greece (G. Stamatoyannopoulos, 1967, personal communication).

Our limited number of deficient males with normal G6PD activity did not show a focal geogra- 
phical distribution. Moreover, we have not detected values of enzyme activity, in their parents, higher than those usually observed in the parents of hemizygous males.

A discussion of the pathogenetic aspects of severe neonatal jaundice in heterozygous females and hemizygous males with the mild type of G6PD deficiency is beyond the scope of the present paper.

\section{Summary}

Examinations were made of 302 full-term newborn infants with severe jaundice (indirect bilirubin $>20 \mathrm{mg} . / 100 \mathrm{ml}$. in $79 \cdot 7 \%$ of the cases) for G6PD deficiency by 3 diagnostic methods, of which the methaemoglobin-elution test proved to be superior. 99 or $32.7 \%$ of the cases were found to be G6PD deficient by the latter method ( 59 males and 40 females): a male : female ratio of 1.47. 8 of the 59 males had normal values of G6PD activity and are probably cases of the mild G6PD deficiency type. The difficulties involved in the diagnosis of G6PD deficiency in the newborn period were discussed.

\section{REFBRENCES}

Beutler, E., and Baluda, M. C. (1963). Methemoglobin reduction: studies of the interaction between cell populations and of the role of methylene blue. Blood, 22, 323.
- Duron, O., and Kelly, B. M. (1963). Improved method for the determination of blood glutathione. $\mathcal{f}$. Lab. clin. Med., 61, 882.

Carson, P. E., and Frischer, H. (1966). Glucose-6-phosphate dehydrogenase deficiency and related disorders of the pentose phosphate pathway. Amer. F. Med., 41, 744.

Doxiadis, S. A., Fessas, Ph., and Valaes, T. (1960). Erythrocyte enzyme deficiency in unexplained kernicterus. Lancet, $2,44$.

- and Valaes, T. (1964). The clinical picture of glucose 6phosphate dehydrogenase deficiency in early infancy. Arch. Dis. Childh., 39, 545.

Fessas, Ph., Doxiadis, S. A., and Valaes, T. (1962). Neonatal jaundice in glucose-6-phosphate dehydrogenase deficient infants. Brit. med. F., 2, 1359.

Freier, S., Mayer, K., Levene, C., and Abrahamov, A. (1965). Neonatal jaundice associated with familial G6PD deficiency in Israel. ibid., 40, 280.

Gall, J. C., Jr., Brewer, G. J., and Dern, R. J. (1965). Studies of glucose-6-phosphate dehydrogenase activity of individual erythrocytes: the methemoglobin-elution test for identification of females heterozygous for G6PD deficiency. Amer. F. hum. Genet., $17,359$.

Gross, R. T., and Hurwitz, R. E. (1958). The pentose phosphate pathway in human erythrocytes. Pediatrics, 22, 453.

Malloy, H. T., and Evelyn, K. A. (1937). The determination of bilirubin with the photoelectric colorimeter. F. biol. Chem., $119,481$.

Sansone, G., Rasore-Quartino, A., and Veneziano, G. (1963). Dimostrazione su strisci di sangue di una doppia popolazione eritrocitaria nelle donne eterozigoti per la deficienza in glucoso6-P deidrogenasi. Pathologica, 55, 371.

Stamatoyannopoulos, G., Panayotopoulos, A., and Papayannopoulou, Th. (1964). Mild glucose-6-phosphate dehydrogenase deficiency in Greek males. Lancet, 2, 932.

Valaes, T., Doxiadis, S. A., and Fessas, P. (1963). Acute hemolysis due to naphthalene inhalation. F. Pediat., 63, 904.

Zannos-Mariolea, L., and Kattamis, C. (1961). Glucose-6-phosphate dehydrogenase deficiency in Greece. Blood, 18, 34 . 